\title{
Multi-residue enantioselective analysis of chiral drugs in freshwater sediments
}

\author{
Abbey Eaglesham ${ }^{1} \cdot$ Arron Scott $^{1} \cdot$ Bruce Petrie $^{1}$ (D)
}

Received: 27 May 2020 / Accepted: 17 June 2020 / Published online: 28 June 2020

(c) The Author(s) 2020

\begin{abstract}
Pharmaceutical and illicit drugs are emerging contaminants found in the environment globally. Many are chiral and stereochemistry plays an important role on their environmental fate and effects. However, investigations at the enantiomeric level are limited, particularly for complex particulate matrices such as sediments. This is due to further sample processing requirements and a lack of suitable analytical methods. Therefore, here a new enantioselective methodology is proposed for 15 drugs in sediment. Sample treatment by accelerated solvent extraction and solid phase extraction was critical for subsequent enantioselective separations. Using liquid chromatography-tandem mass spectrometry, a Chiral-V enantioselective column enabled multi-residue separations of anti-depressants, beta-blockers, beta-agonist, anti-histamine and stimulants. Method trueness for all enantiomers was $86-121 \%$ and method quantitation limits were below $3 \mathrm{ng} \mathrm{g}^{-1}$ dry weight. Application of the method revealed the enantiomeric composition of fluoxetine, amphetamine, propranolol, venlafaxine and citalopram in sediment for the first time. All drugs except venlafaxine were present in non-racemic form, i.e. unequal enantiomer concentrations. This is significant considering drug toxicity towards benthic organisms could be enantiospecific.
\end{abstract}

Keywords Vancomycin $\cdot$ Metabolite $\cdot$ Septic tank $\cdot$ Sewage $\cdot$ Wastewater $\cdot$ River

\section{Introduction}

Pharmaceutical and illicit drugs are emerging contaminants as their fate and effects in the environment are not fully understood (Cizmas et al. 2015; Wilkinson et al. 2017). The main source of drugs in the environment is the discharge of effluent from centralised wastewater treatment plants. However, septic tanks can play a significant role with $20 \%$ of United States households served by a septic tank or similar system (Schaider et al. 2017). In Scotland, 7\% of the population is estimated to use a septic tank (Ramage et al. 2019). Nevertheless, little attention has been given to the impact of septic tanks to surrounding aquatic systems with respect to drugs.

Electronic supplementary material The online version of this article (https://doi.org/10.1007/s10311-020-01041-6) contains supplementary material, which is available to authorised users.

Bruce Petrie

b.r.petrie@rgu.ac.uk

1 School of Pharmacy and Life Sciences, Robert Gordon University, Aberdeen AB10 7GJ, UK
Drug stereochemistry plays an essential role in the environmental behaviour of a drug. Approximately, $50 \%$ of drugs are chiral and exist as two or more enantiomers (KasprzykHordern 2010). Most drugs are dispensed in racemic form, i.e. equal concentration of all enantiomers, despite most of the pharmacological activity normally residing with one enantiomer. However, chiral drugs can be subject to enantiospecific metabolism in the human body and during wastewater treatment (Ribeiro et al. 2012). Therefore in the environment it is common to find chiral drugs enriched with one enantiomer. This is significant as enantiospecific toxicity can occur in the environment (Stanley et al. 2007). For example, $S(+)$-fluoxetine is $\sim 10$ times more toxic towards the protozoa Tetrahymena thermophila than $R(-)$-fluoxetine (De Andrés et al. 2009). Despite this knowledge there is still a lack of studies undertaken in the environment at the enantiomeric level, particularly for particulate matrices such as sediments. A contributing factor is the lack of good analytical methodologies available for these complex matrices.

Multi-residue enantioselective methods exist for biosolids applied to farmland as fertiliser (Evans et al. 2015) and soils (Petrie et al. 2018). However, no such methods exist for river sediments. Previously developed methods for sediments are 
limited to a single therapeutic drug group. For example, methods exist for the anti-inflammatories ibuprofen, ketoprofen and flurbiprofen (Yuan et al. 2018), the antibiotic flumequine and its metabolite 7-hydroxyflumequine (Xue et al. 2018) and the antifungals econazole, ketoconazole and miconazole (Huang et al. 2013). However, numerous other chiral drugs have been reported in sediments, (Vazquez-Roig et al. 2010; Silva et al. 2011; Bagnis et al. 2018) with no information on their enantiomeric composition. Therefore, the objectives of the study were (i) to establish a new methodology for multi-residue enantioselective profiling of chiral drugs in sediments, and (ii) to determine the enantiomeric composition of chiral drugs present in sediments impacted by wastewater treatment plants and septic tanks.

\section{Experimental}

\section{Materials}

Analytical reference and deuterated surrogate standards were purchased from Sigma Aldrich (Gillingham, UK) and Toronto Research Chemicals (North York, Canada). The standards were $R / S( \pm)$-amphetamine, $R / S( \pm)$-methamphetamine, $R / S( \pm)$-atenolol, $R / S( \pm)$-chlorpheniramine, $R / S( \pm)$-citalopram, $R / S( \pm)$-desmethylcitalopram, $R / S( \pm)$-fluoxetine, $R / S( \pm)$-propranolol, $R / S( \pm)$-salbutamol, $R / S( \pm)$-venlafaxine, $R / S( \pm)$-desmethylvenlafaxine, $R / S( \pm$ )-bisoprolol, $R / S( \pm)$-acebutolol, $R / S( \pm)$-metoprolol and $R / S( \pm)$-sotalol (Table $\mathrm{S} 1$ ). The deuterated surrogates were $R / S( \pm)$-amphetamine- $\mathrm{d}_{11}, R / S( \pm)$-methamphetamine$\mathrm{d}_{11}, R / S( \pm)$-atenolol- $\mathrm{d}_{7}, R / S( \pm)$-chlorpheniramine- $\mathrm{d}_{6}$, $R / S( \pm)$-citalopram- $\mathrm{d}_{6}, R / S( \pm)$-fluoxetine- $\mathrm{d}_{6}, R / S( \pm)$-propranolol- $\mathrm{d}_{7}, R / S( \pm)$-salbutamol- $\mathrm{d}_{3}, R / S( \pm)$-venlafaxine- $\mathrm{d}_{6}$, $R / S( \pm)$-bisoprolol-d $\mathrm{d}_{5}, R / S( \pm)$-acebutolol- $\mathrm{d}_{5}, R / S( \pm)$-metoprolol- $\mathrm{d}_{7}$ and $R / S( \pm)$-sotalol- $\mathrm{d}_{6}$. Mixed calibration standards were prepared in methanol at $0.01-250 \mathrm{ng} \mathrm{mL}^{-1}$ (including $200 \mathrm{ng} \mathrm{mL}^{-1}$ of each deuterated surrogate). These were stored at $-20^{\circ} \mathrm{C}$ and prepared weekly. HPLC grade methanol, acetic acid and ammonium acetate were purchased from Fisher Scientific (Loughborough, UK). Ultrapure water was $18.2 \mathrm{M} \Omega \mathrm{cm}^{-1}$ quality. Sediment $(\sim 500 \mathrm{~g})$ from the top $5 \mathrm{~cm}$ surface layer was collected for method development from the River Don, Aberdeenshire. This was frozen at $-20^{\circ} \mathrm{C}$ until further processing.

\section{Sample extraction}

Sediments were freeze dried and sieved ( $2 \mathrm{~mm}$ ). Two grams of samples was spiked with a methanolic mixture of all deuterated surrogates at $50 \mathrm{ng} \mathrm{g}^{-1}$ and left for $1 \mathrm{~h}$. Samples were mixed with $1 \mathrm{~g}$ diatomaceous earth and packed into $10 \mathrm{~mL}$ accelerated solvent extraction cells (Fisher Scientific). The remaining cell volume was filled with Ottawa sand and two 2-4 $\mu \mathrm{m}$ Dionex glass fibre filters (Fisher Scientific) fitted at each end. Sample extraction was performed using a Dionex ASE 350 (California, USA) system. The final method utilised an extraction solvent of 50:50 water:methanol at $100^{\circ} \mathrm{C}$. Two extraction cycles were undertaken per cell with the following settings: $5 \mathrm{~min}$ pre-heat, $5 \mathrm{~min}$ heat, $5 \mathrm{~min}$ static extraction time, $60 \%$ solvent flush volume, $150 \mathrm{~s}$ nitrogen purge and 1500 psi pressure. During development the influence of sample mass, extraction temperature and solvent composition to enantiomer recovery were investigated. Collected extracts $(\sim 22 \mathrm{~mL})$ were diluted to $250 \mathrm{~mL}$ using water $(<10 \%$ methanol content). Samples were loaded $\left(5 \mathrm{~mL} \mathrm{~min}^{-1}\right.$ ) onto Oasis HLB solid phase extraction cartridges $(3 \mathrm{~mL}, 60 \mathrm{mg}$, Waters, Manchester, UK) preconditioned with $2 \mathrm{~mL}$ methanol and $2 \mathrm{~mL}$ water at $1 \mathrm{~mL} \mathrm{~min}^{-1}$. Enantiomer elution was in $4 \mathrm{~mL}$ methanol at $1 \mathrm{~mL} \mathrm{~min}^{-1}$. Extracts were dried at $40{ }^{\circ} \mathrm{C}$ under nitrogen and reconstituted in $0.5 \mathrm{~mL}$ mobile phase.

\section{Enantioselective liquid chromatography-tandem mass spectrometry}

Chromatographic analysis was undertaken using an Agilent 1200 series liquid chromatography system (Cheshire, UK) using an InfinityLab Poroshell 120 Chiral-V column $(150 \times 2.1 \mathrm{~mm} ; 2.7 \mu \mathrm{m}$ particle size $)$ fitted with a $0.2 \mu \mathrm{m}$ pre-filter. A polar ionic mobile phase consisting of $2 \mathrm{mM}$ ammonium acetate in methanol containing $0.01 \%$ acetic acid at a flow rate of $0.15 \mathrm{~mL} \mathrm{~min}^{-1}$ was used (McKenzie et al. 2020). The column temperature was $15^{\circ} \mathrm{C}$ whilst the injection volume was $10 \mu \mathrm{L}$. The detector was an Agilent 6420 triple quadrupole in positive electrospray ionisation mode. The capillary voltage was $4,000 \mathrm{~V}$ with a desolvation temperature of $350{ }^{\circ} \mathrm{C}$ and nitrogen gas flow of $12 \mathrm{~L} \mathrm{~min}^{-1}$. The nebulising pressure was $50 \mathrm{psi}$. Nebulising, desolvation and collision gases were nitrogen. Multiple reaction monitoring transitions and instrument performance data are compiled in Table S2 and Table S3.

\section{Study site}

A sub-catchment of the River Don, Aberdeenshire known to be impacted by septic tank discharge and not any centralised wastewater treatment plants was focused upon (Ramage et al. 2019). Five sampling locations were selected and $\sim 100 \mathrm{~g}$ of sediment from the top $5 \mathrm{~cm}$ surface layer was collected. Samples were transported to the laboratory on ice and frozen at $-20{ }^{\circ} \mathrm{C}$ in aluminium foil until further processing (as described in Sect. 2.2). Sediment was also collected from the River Don itself, approximately $7 \mathrm{~km}$ downstream of the nearest centralised wastewater treatment plant. Samples 
were collected during October 2019 and all analysis was in triplicate.

\section{Results and discussion}

\section{Method development}

Vancomycin chiral selectors are popular due to their multiresidue separation capabilities (Ribeiro et al. 2013; Evans et al. 2015; Petrie et al. 2018). A Poroshell 120 Chiral-V column was used due to the comparatively short run time (30 min) achievable for multi-residue analysis over other commercially available vancomycin columns (McKenzie et al. 2020). Operation in polar ionic mode using a mobile phase of $2 \mathrm{mM}$ ammonium acetate in methanol containing $0.01 \%$ acetic acid facilitated simultaneous enantioseparations (Fig. 1). In total, 12 of 15 drugs achieved the minimum enantiomer resolution $\left(\mathrm{R}_{\mathrm{S}}\right)$ threshold of 1 for quantitative purposes (Evans et al. 2015). The remaining drugs had enantiomer $\mathrm{R}_{\mathrm{S}}$ of $0.5-0.8$ and the valley drop method was used for integration (Camacho-Muñoz and Kasprzyk-Hordern 2017). The inclusion of $R / S( \pm)$-desmethylcitalopram required a run time of $40 \mathrm{~min}$ (Fig. 1). Nevertheless, this remains shorter than previous enantioselective methods for $R / S( \pm)$-desmethylcitalopram which require $\geq 80 \mathrm{~min}$ (Evans et al. 2015).

Accelerated solvent extraction was used due to its previous success for extraction of drugs from soil followed by enantioselective analysis (Petrie et al. 2018). However, it was not possible to directly apply this extraction method to sediments. Extraction of $5 \mathrm{~g}$ (freeze dried) organic rich sediment resulted in loss of chiral recognition for most drugs in subsequent enantioselective analysis. Therefore, a new

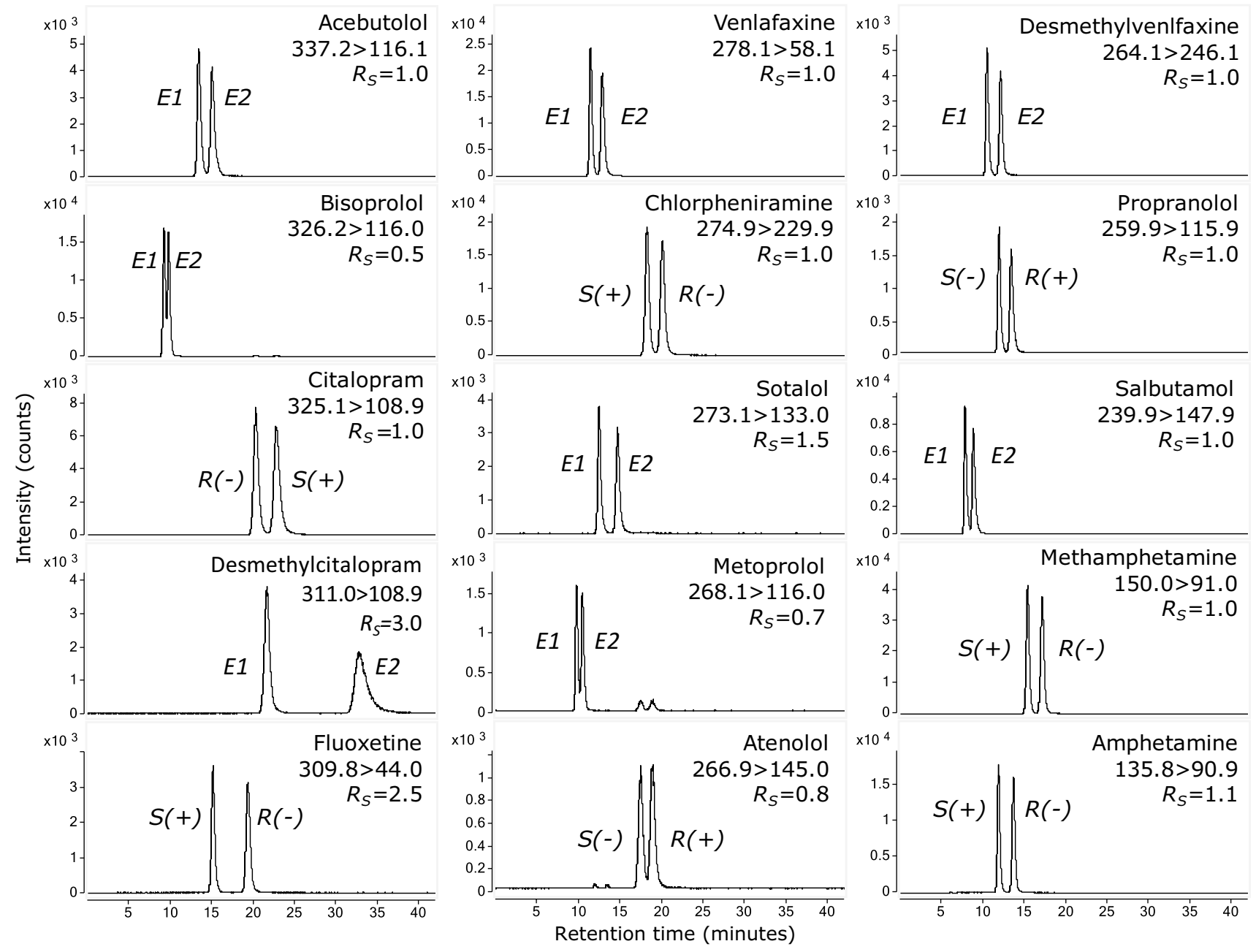

Fig. 1 Enantioselective liquid chromatography-tandem mass spectrometry chromatograms of studied drugs at $100 \mathrm{ng} \mathrm{mL}^{-1}$. Each chromatogram shows the monitored MS/MS transition and enantiomer resolution. Key: $E 1$, enantiomer 1; $E 2$, enantiomer 2 (where order of enantiomer elution is not known). $S(-), S(-)$-enantiomer; $R(+)$, $R(+)$-enantiomer; $S(+), S(+)$-enantiomer; $R(-), R(-)$-enantiomer (where order of enantiomer elution is known) 
(A)
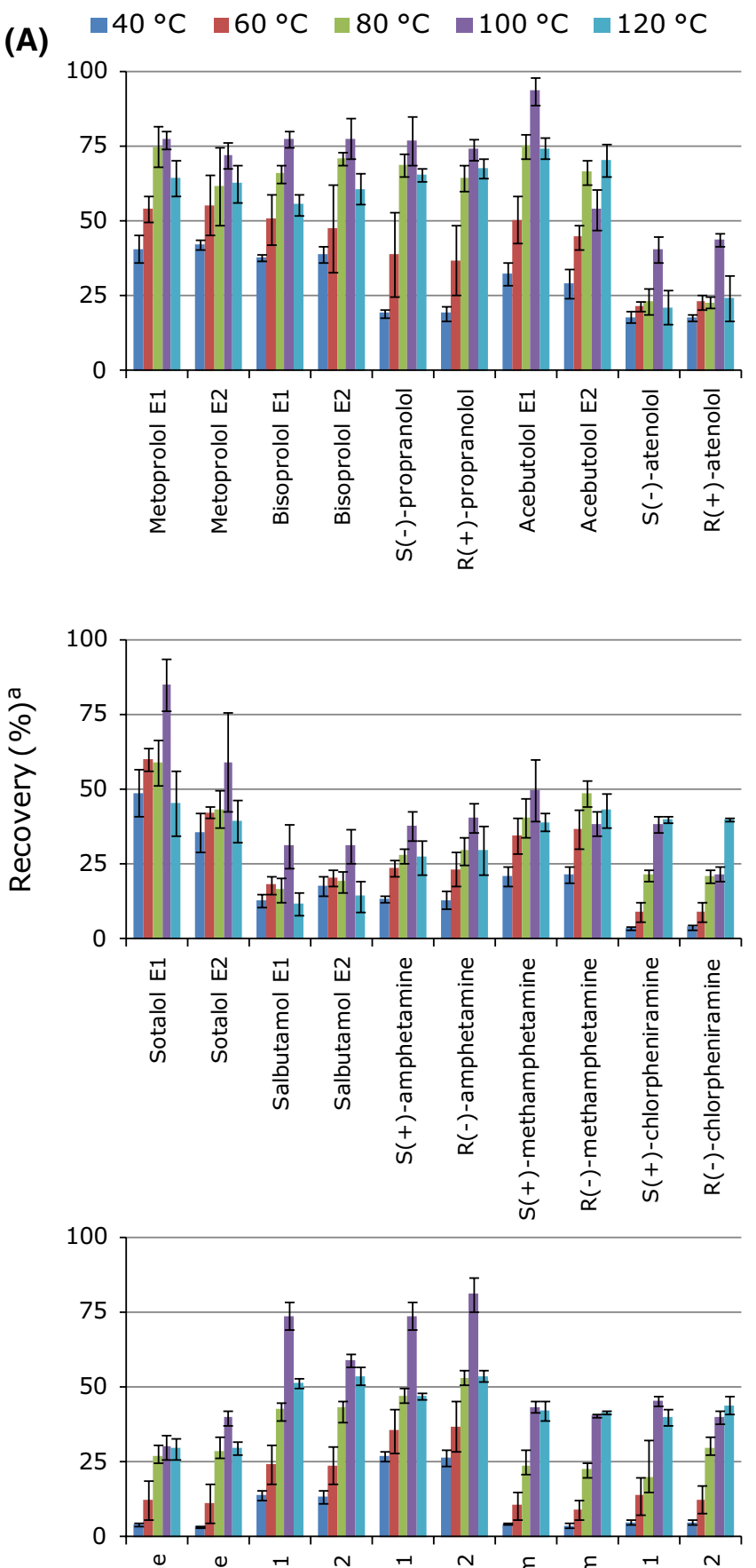

(B)
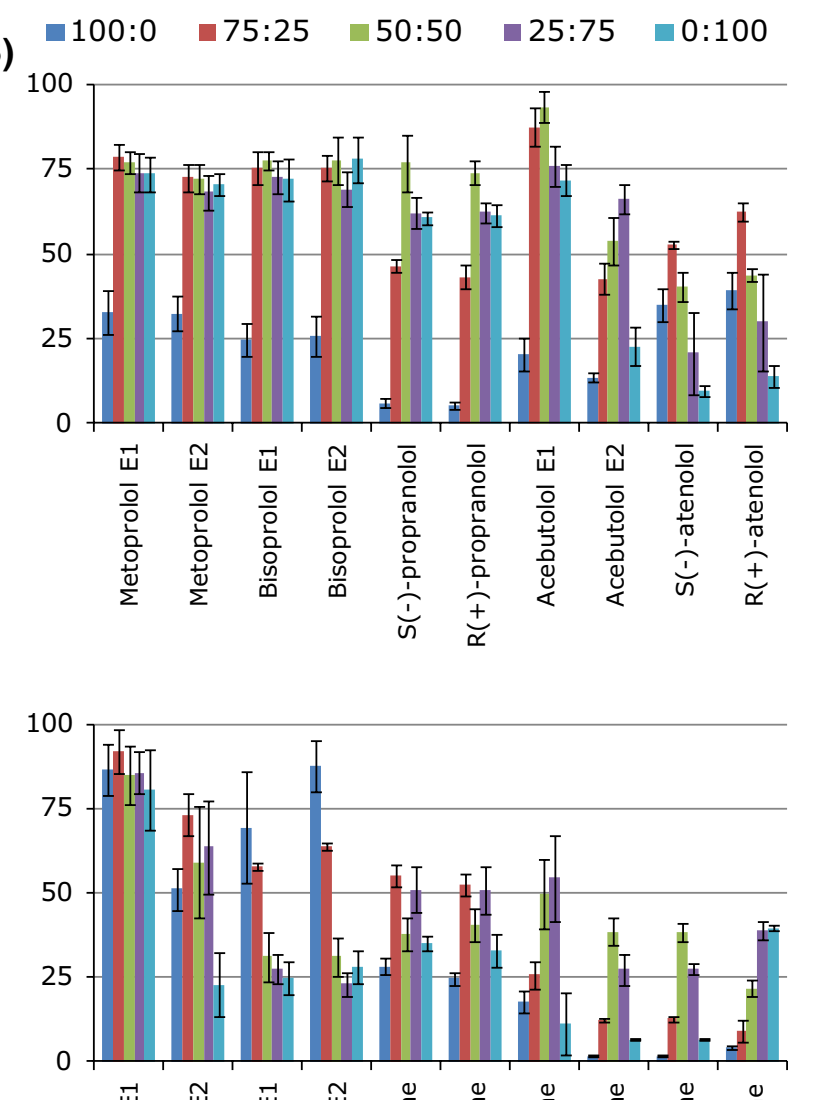

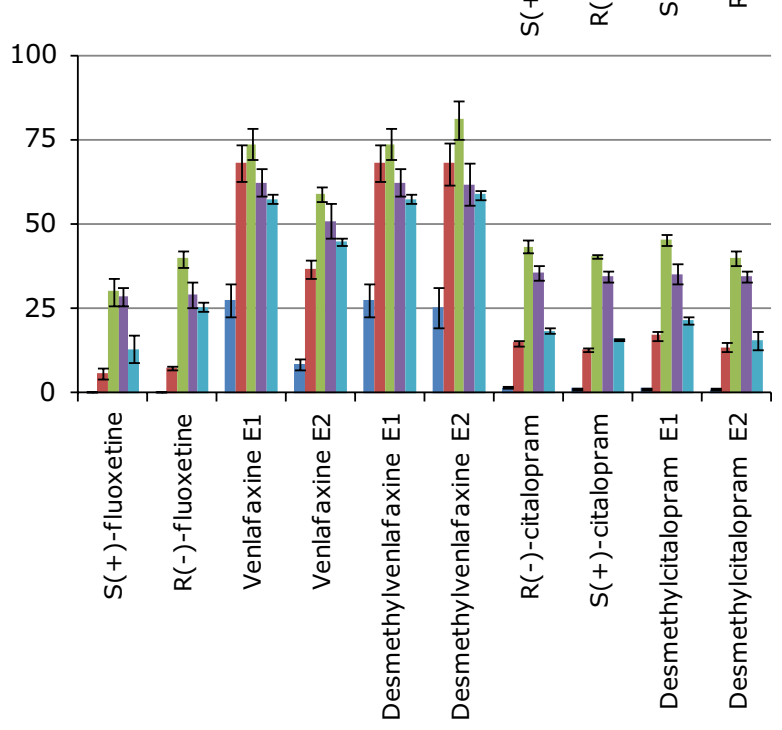

Drug enantiomer 
4Fig. 2 Influence of extraction temperature (a) and water:methanol extraction solvent composition (b) on enantiomer recovery. Note: at varying extraction temperature the solvent composition was 50:50 water:methanol (a), and under varying water:methanol extraction solvent compositions the temperature was $100{ }^{\circ} \mathrm{C}(\mathbf{b})$. The spiking concentration was $50 \mathrm{ng} \mathrm{g}^{-1}$ and all analysis was performed in triplicate. Key: aRecovery $(\%)=\frac{\left(\mathrm{PA}_{\mathrm{S}}-\mathrm{PA}_{\mathrm{U}}\right)}{\mathrm{PA}_{\mathrm{STD}}}$. where $\mathrm{PA}_{\mathrm{S}}$ is peak area of the extracted spiked sample, $\mathrm{PA}_{\mathrm{U}}$ is the peak area of the unspiked sample and $\mathrm{PA}_{\mathrm{STD}}$ is the peak area of a corresponding standard solution assuming $100 \%$ recovery through the extraction process

extraction protocol was needed. The maximum sample mass extractable which ensured no loss of chiral recognition was $2 \mathrm{~g}$. Due to the low $\mathrm{ng} \mathrm{g}^{-1}$ drug concentrations in sediments (Vazquez-Roig et al. 2010; Silva et al. 2011), further development work was undertaken to ensure maximum recoveries were achieved. Both solvent extraction temperature and solvent composition were studied as they have considerable influence on drug recovery (Petrie et al. 2018).

Enantiomer recovery was investigated at extraction temperatures of 40,60, 80, 100 and $120{ }^{\circ} \mathrm{C}$. Findings showed $\geq 80{ }^{\circ} \mathrm{C}$ was required to achieve the greatest recovery of the more hydrophobic drugs fluoxetine, venlafaxine, chlorpheniramine and citalopram $\left(\log \mathrm{K}_{\mathrm{OW}}>3\right.$ Table $\left.\mathrm{S} 1\right)$. Recovery of $40 \%$ (12/30) of the studied enantiomers was significantly greater at $100{ }^{\circ} \mathrm{C}$ than any other temperature (Fig. 2). However, significantly higher recovery was achieved for some enantiomers at a different temperature (e.g. $R(-)$ chlorpheniramine at $\left.120{ }^{\circ} \mathrm{C}\right)$. Nevertheless, the best overall recovery for the suite of drugs investigated was at $100{ }^{\circ} \mathrm{C}$. Analyte losses can be from the extraction processes but also by signal suppression during electro-spray ionisation (Petrie et al. 2018). Therefore, improved extraction at higher temperature can be compensated by increased signal suppression. This could be the case at $120^{\circ} \mathrm{C}$ as sample extracts were visibly 'dirtier' than other extraction temperatures.

The different water:methanol extraction solvent compositions investigated were 100:0, 75:25, 50:50, 25:75 and 0:100. Methanol was selected as the organic solvent due to the greater performance over other solvents such as acetonitrile (Nieto et al. 2010). Greatest simultaneous recoveries were achieved using 50:50 water:methanol (Fig. 2). Under such extraction conditions $\left(2 \mathrm{~g}\right.$ sediment extracted at $100{ }^{\circ} \mathrm{C}$ using 50:50 water:methanol) enantiomer recoveries ranged from $22 \pm 3 \%$ for $R(-)$-chlorpheniramine to $93 \pm 5 \%$ for acebutolol- $E 1$. This range of recoveries is comparable to multi-residue achiral methods for sediments (Vazquez-Roig et al. 2010).

\section{Method performance}

Performance of the methodology was assessed in terms of trueness, signal suppression and sensitivity. Method trueness (accounting for deuterated surrogate response) was determined at enantiomer concentrations of 10, 50 and $100 \mathrm{ng} \mathrm{g}^{-1}$. All drug enantiomers displayed method trueness in the range $86-121 \%$ (Table 1). Both desmethylvenlafaxine and desmethylcitalopram had greatest deviation from $100 \%$ as they did not have their own deuterated surrogate. Instead they were quantified using the corresponding enantiomer of venlafaxine- $\mathrm{d}_{6}$ or citalopram- $\mathrm{d}_{6}$, respectively, and can only be considered semi-quantitative. Method precision was $\leq 20 \%$ for all enantiomers (Table 1 ).

Signal suppression during electrospray ionisation (i.e. loss of response due to co-extracted matrix quenching analyte signal) ranged from $-28 \%$ (i.e. signal enhancement) for salbutamol-E2 to $42 \%$ for $R(-)$-citalopram (Table 1). Such losses are low considering it is not uncommon to encounter $>50 \%$ suppression (Vazquez-Roig et al. 2010; Petrie et al. 2018). However, several drugs including citalopram, salbutamol, acebutolol, metoprolol, atenolol and atenolol demonstrated enantiospecific suppression (e.g. $>10 \%$ between enantiomers). To demonstrate, signal suppression of acebutolol-E1 and acebutolol- $E 2$ were $-4 \%$ and $34 \%$, respectively (Table 1). Such observations demonstrate the necessity of using deuterated surrogates for enantioselective analysis of sediments.

Method sensitivity was assessed by determining the method detection and quantitation limits. Method quantitation limits were $\leq 3 \mathrm{ng} \mathrm{g}^{-1}$ for all enantiomers with the majority being $<1 \mathrm{ng} \mathrm{g}^{-1}$ (Table 1). Such limits enable the determination of drugs at the enantiomeric level considering the concentrations previously reported in sediments (Vazquez-Roig et al. 2010; Silva et al. 2011). Furthermore, the method detection and quantitation limits are similar to previously published achiral methodologies for sediments (Vazquez-Roig et al. 2010; Al-Khazrajy and Boxall 2017).

\section{Enantiomeric profiling of chiral drugs in sediments}

The new methodology was applied to freshwater sediments collected in North-East Scotland (Fig. 3). Sampling focused on a small stream impacted by septic tank discharge (Ramage et al. 2019). The receiving river impacted by both wastewater treatment plant effluent and septic tanks was also sampled. Within the small stream, sediment was collected from a control site with no upstream households. Here, the surrounding land use was arable crop with no biosolids or animal slurry applications within the last two years. No drug enantiomers were detected at this location (Fig. 3).

Samples 1-3 were collected downstream of a suspected septic tank effluent discharge point (without dissipation though a soak away) (Ramage et al. 2019). Both fluoxetine and amphetamine were present. Concentrations of $S(+)$-fluoxetine ranged from 1.6 to $5.0 \mathrm{ng} \mathrm{g}^{-1}$ and 
Table 1 Performance data of the accelerated solvent extraction-solid phase extraction-enantioselective liquid chromatography-tandem mass spectrometry methodology

\begin{tabular}{|c|c|c|c|c|c|c|c|}
\hline \multirow[t]{2}{*}{ Drug group } & \multirow[t]{2}{*}{ Enantiomer } & \multicolumn{3}{|c|}{ Method trueness $(\% \pm \mathrm{SD})^{\mathrm{a}}$} & \multirow{2}{*}{$\begin{array}{l}\text { Signal sup- } \\
\text { pression }(\%)^{b}\end{array}$} & \multirow[t]{2}{*}{$\operatorname{MDL}\left(\operatorname{ng~g}^{-1}\right)^{\mathrm{c}}$} & \multirow[t]{2}{*}{ MQL $\left(\mathrm{ng} \mathrm{g}^{-1}\right)^{\mathrm{d}}$} \\
\hline & & $10 \mathrm{ng} \mathrm{g}^{-1}$ & $50 \mathrm{ng} \mathrm{g}^{-1}$ & $100 \mathrm{ng} \mathrm{g}^{-1}$ & & & \\
\hline \multirow[t]{12}{*}{ Beta-blocker } & Metoprolol-E1 & $96 \pm 12$ & $99 \pm 4$ & $87 \pm 3$ & 3 & 0.26 & 0.81 \\
\hline & Metoprolol-E2 & $96 \pm 15$ & $100 \pm 5$ & $95 \pm 4$ & 13 & 0.28 & 0.87 \\
\hline & Bisoprolol-E1 & $104 \pm 11$ & $101 \pm 5$ & $90 \pm 2$ & 14 & 0.03 & 0.13 \\
\hline & Bisoprolol-E2 & $106 \pm 12$ & $97 \pm 4$ & $99 \pm 3$ & 21 & 0.03 & 0.13 \\
\hline & $S(-)$-propranolol & $101 \pm 15$ & $102 \pm 4$ & $95 \pm 1$ & 17 & 0.10 & 0.32 \\
\hline & $R(+)$-propranolol & $94 \pm 2$ & $100 \pm 4$ & $102 \pm 3$ & 18 & 0.10 & 0.34 \\
\hline & Acebutolol-E1 & $102 \pm 8$ & $95 \pm 5$ & $91 \pm 4$ & -4 & 0.03 & 0.11 \\
\hline & Acebutolol-E2 & $104 \pm 18$ & $99 \pm 2$ & $101 \pm 3$ & 34 & 0.05 & 0.19 \\
\hline & $S(-)$-atenolol & $107 \pm 9$ & $102 \pm 1$ & $95 \pm 4$ & 19 & 0.91 & 3.05 \\
\hline & $R(+)$-atenolol & $100 \pm 7$ & $102 \pm 1$ & $101 \pm 3$ & 2 & 0.85 & 2.84 \\
\hline & Sotalol- $E 1$ & $96 \pm 5$ & $102 \pm 3$ & $90 \pm 2$ & 2 & 0.38 & 1.24 \\
\hline & Sotalol-E2 & $95 \pm 9$ & $98 \pm 4$ & $96 \pm 6$ & 29 & 0.55 & 1.78 \\
\hline \multirow[t]{2}{*}{ Beta-agonist } & Salbutamol-E1 & $106 \pm 1$ & $103 \pm 3$ & $92 \pm 2$ & -15 & 0.08 & 0.24 \\
\hline & Salbutamol-E2 & $102 \pm 3$ & $98 \pm 2$ & $101 \pm 3$ & -28 & 0.08 & 0.24 \\
\hline \multirow[t]{4}{*}{ Stimulant } & $S(+)$-amphetamine & $104 \pm 13$ & $98 \pm 2$ & $88 \pm 4$ & 17 & 0.07 & 0.26 \\
\hline & $R(-)$-amphetamine & $103 \pm 1$ & $101 \pm 2$ & $98 \pm 3$ & 11 & 0.06 & 0.24 \\
\hline & $S(+)$-methamphetamine & $104 \pm 16$ & $100 \pm 3$ & $93 \pm 3$ & 26 & 0.05 & 0.15 \\
\hline & $R(-)$-methamphetamine & $99 \pm 17$ & $95 \pm 3$ & $99 \pm 6$ & 28 & 0.07 & 0.20 \\
\hline \multirow[t]{2}{*}{ Anti-histamine } & $S(+)$-chlorpheniramine & $103 \pm 7$ & $86 \pm 4$ & $95 \pm 13$ & 21 & 0.19 & 0.64 \\
\hline & $R(-)$-chlorpheniramine & $103 \pm 12$ & $91 \pm 6$ & $96 \pm 9$ & 22 & 0.34 & 1.14 \\
\hline \multirow[t]{10}{*}{ Anti-depressant } & $S(+)$-fluoxetine & $102 \pm 11$ & $98 \pm 6$ & $93 \pm 4$ & 27 & 0.42 & 1.33 \\
\hline & $R(-)$-fluoxetine & $99 \pm 7$ & $94 \pm 5$ & $99 \pm 6$ & 20 & 0.31 & 1.00 \\
\hline & Venlafaxine- $E 1$ & $90 \pm 17$ & $99 \pm 4$ & $94 \pm 7$ & 11 & 0.03 & 0.14 \\
\hline & Venlafaxine- $E 2$ & $100 \pm 20$ & $103 \pm 3$ & $101 \pm 5$ & 13 & 0.04 & 0.17 \\
\hline & Desmethylvenlafaxine- $E 1$ & $113 \pm 13$ & $109 \pm 7$ & $109 \pm 11$ & 24 & 0.14 & 0.47 \\
\hline & Desmethylvenlafaxine- $E 2$ & $112 \pm 17$ & $121 \pm 5$ & $115 \pm 14$ & 22 & 0.12 & 0.43 \\
\hline & $R(-)$-citalopram & $103 \pm 16$ & $102 \pm 7$ & $103 \pm 11$ & 42 & 0.29 & 0.99 \\
\hline & $S(+)$-citalopram & $104 \pm 11$ & $102 \pm 10$ & $105 \pm 8$ & 30 & 0.30 & 1.04 \\
\hline & Desmethylcitalopram- $E 1$ & $120 \pm 13$ & $112 \pm 11$ & $105 \pm 3$ & 32 & 0.28 & 0.94 \\
\hline & Desmethylcitalopram- $E 2$ & $112 \pm 8$ & $104 \pm 16$ & $108 \pm 17$ & 37 & 0.31 & 1.06 \\
\hline
\end{tabular}

SD, standard deviation; MDL, method detection limit; MQL, method quantitation limit

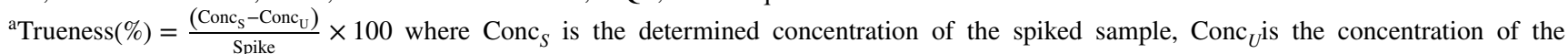
unspiked sample and Spike is the spiked concentration.

${ }^{\mathrm{b}}$ Signal suppression $(\%)=100-\left(\frac{\text { Slope }_{\mathrm{M}}}{\text { Slope }_{\mathrm{S}}} \times 100\right)$ where Slope ${ }_{M M}$ is the slope of the external calibration prepared in matrix and Slope ${ }_{S}$ is the slope of the external calibration prepared in methanol.

${ }^{\mathrm{c}} \operatorname{MDL}\left(\mathrm{ng} \mathrm{g}^{-1}\right)=\frac{(\mathrm{S} . \mathrm{IDL} \times 100)}{(\operatorname{Rec} \times \mathrm{CF})}$

${ }^{\mathrm{d}} \mathrm{MQL}\left(\mathrm{ng} \mathrm{g}^{-1}\right)=\frac{(\mathrm{S} . \mathrm{IQL} \times 100)}{(\operatorname{Rec} \times \mathrm{CF})}$ where $S$ is the volume of sample used for extraction divided by the mass of sample extracted $\left(\mathrm{mL} \mathrm{g}^{-1}\right), I D L$ and $I Q L$ are the instrument detection and quantitation limits, respectively $\left(\mathrm{ng} \mathrm{mL}^{-1}\right), \operatorname{Rec}$ is the absolute recovery (\%, not accounting for the deuterated surrogate response) and $C F$ is the concentration factor.

$R(-)$-fluoxetine from 1.0 to $3.4 \mathrm{ng} \mathrm{g}^{-1}$ (Fig. 3). Chiral drug composition was described using enantiomeric fraction:

Enantiomeric fraction $=\frac{(+)}{[(+)+(-)]}$
Here (+) is the concentration of the (+)-enantiomer and (-) is the concentration of the (-)-enantiomer. In each sediment an enrichment of $S(+)$-fluoxetine resulted in enantiomeric fractions of $0.59-0.61$.. The enantiomeric composition of 


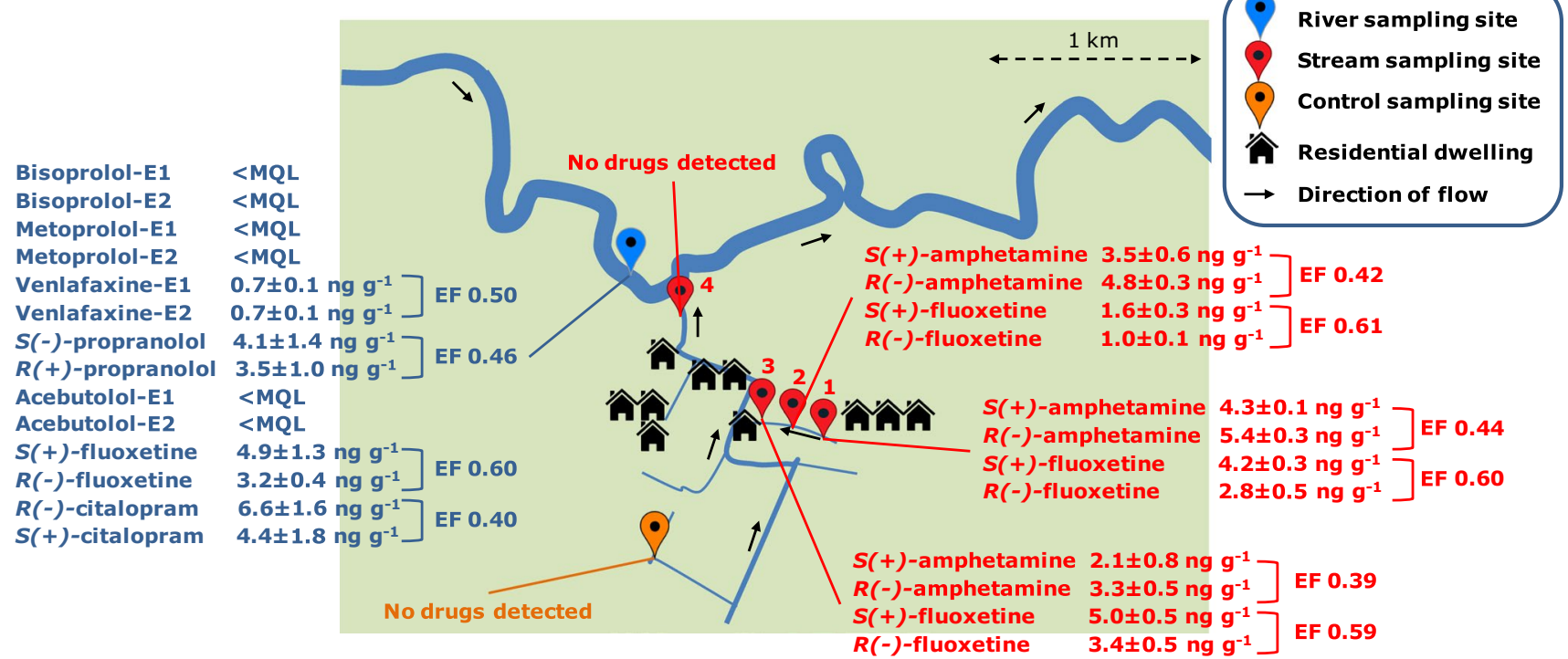

Fig. 3 Enantiomer concentrations and enantiomeric fractions of those drugs detected in sediments collected from a small stream $(<0.1$ $\left.\mathrm{m}^{3} \mathrm{~s}^{-1}\right)$ impacted by septic tank discharge and a receiving river $(9.5$ $\mathrm{m}^{3} \mathrm{~s}^{-1}$ ) impacted by wastewater treatment plants and septic tanks. Key: EF, enantiomeric fraction, $<\mathrm{MQL}$, below method quantitation limit

were non-racemic (enantiomeric fraction $\neq 0.50$ ). Therefore, further investigation is needed on the enantiospecific fate and effects of chiral drugs in freshwater sediments.

\section{Conclusion}

Reported here is the first analytical method for the multiresidue enantioselective profiling of chiral drugs in river sediment. Application of the methodology revealed the enantiomeric composition of several drug in sediment for the first time including fluoxetine, amphetamine, propranolol, venlafaxine and citalopram. Most of the drugs were present in non-racemic form demonstrating further enantiospecific investigations are needed in sediments. Such studies can be facilitated using this new multi-residue methodology.

Acknowledgements Support by the Analytical Chemistry Trust Fund is acknowledged.

Open Access This article is licensed under a Creative Commons Attribution 4.0 International License, which permits use, sharing, adaptation, distribution and reproduction in any medium or format, as long as you give appropriate credit to the original author(s) and the source, provide a link to the Creative Commons licence, and indicate if changes were made. The images or other third party material in this article are included in the article's Creative Commons licence, unless indicated otherwise in a credit line to the material. If material is not included in 
the article's Creative Commons licence and your intended use is not permitted by statutory regulation or exceeds the permitted use, you will need to obtain permission directly from the copyright holder. To view a copy of this licence, visit http://creativecommons.org/licenses/by/4.0/.

\section{References}

Al-Khazrajy OSA, Boxall ABA (2016) Impacts of compound properties and sediment characteristics on the sorption behaviour of pharmaceuticals in aquatic systems. J Hazard Mater 317:198-209. https://doi.org/10.1016/j.jhazmat.2016.05.065

Al-Khazrajy OSA, Boxall ABA (2017) Determination of pharmaceuticals in freshwater sediments using ultrasonic-assisted extraction with SPE clean-up and HPLC-DAD or LC-ESI-MS/MS detection. Anal Methods 9(28):4190-4200. https://doi.org/10.1039/ c7ay00650k

Bagnis S, Fitzsimons MF, Snape J et al (2018) Processes of distribution of pharmaceuticals in surface freshwaters: implications for risk assessment. Environ Chem Lett 16:1193-1216. https://doi. org/10.1007/s10311-018-0742-7

Camacho-Muñoz D, Kasprzyk-Hordern B (2017) Simultaneous enantiomeric analysis of pharmacologically active compounds in environmental samples by chiral LC-MS/MS with a macrocyclic antibiotic stationary phase. J Mass Spectrom 52(2):94-108. https ://doi.org/10.1002/jms.3904

Cizmas L, Sharma VK, Gray CM, McDonald TJ (2015) Pharmaceuticals and personal care products in waters: occurrence, toxicity, and risk. Environ Chem Lett 13:381-394. https://doi.org/10.1007/ s10311-015-0524-4

De Andrés F, Castañeda G, Rios A (2009) Use of toxicity assays for enantiomeric discrimination of pharmaceutical substances. Chirality 21(8):751-759. https://doi.org/10.1002/chir.20675

Evans SE, Davies P, Lubben A et al (2015) Determination of chiral pharmaceuticals and illicit drugs in wastewater and sludge using microwave assisted extraction, solid-phase extraction and chiral liquid chromatography coupled with tandem mass spectrometry. Anal Chim Acta 882:112-126. https://doi.org/10.1016/j. aca.2015.03.039

Fono LJ, Sedlak DL (2005) Use of the chiral pharmaceutical propranolol to identify sewage discharges into surface waters. Environ Sci Technol 39(23):9244-9252. https://doi.org/10.1021/es047965t

Huang Q, Wang Z, Wang C et al (2013) Chiral profiling of azole antifungals in municipal wastewater and recipient rivers of the Pearl River Delta. China Environ Sci Pollut Res 20(12):8890-8899. https://doi.org/10.1007/s11356-013-1862-z

Kasprzyk-Hordern B (2010) Pharmacologically active compounds in the environment and their chirality. Chem Soc Rev 39(11):44664503. https://doi.org/10.1039/c000408c

McKenzie K, Moffat CF, Petrie B (2020) Multi-residue enantioselective determination of emerging drug contaminants in seawater by solid phase extraction and liquid chromatography-tandem mass spectrometry. Anal Methods 12:2881-2892. https://doi. org/10.1039/D0AY00801J

Nieto A, Borrull F, Pocurull E et al (2010) Pressurized liquid extraction: A useful technique to extract pharmaceuticals and personalcare products from sewage sludge. Trends Anal Chem 29(7):752764. https://doi.org/10.1016/j.trac.2010.03.014

Petrie B, Mrazova J, Kasprzyk-Hordern B et al (2018) Multi-residue analysis of chiral and achiral trace organic contaminants in soil by accelerated solvent extraction and enantioselective liquid chromatography tandem-mass spectrometry. J Chromatogr A 1572:62-71

Ramage S, Camacho-Muñoz D, Petrie B (2019) Enantioselective LC-MS/MS for anthropogenic markers of septic tank discharge. Chemosphere 219:191-201. https://doi.org/10.1016/j.chemospher e.2018.12.007

Ribeiro AR, Castro PML, Tiritan ME (2012) Chiral pharmaceuticals in the environment. Environ Chem Lett 10:239-253. https://doi. org/10.1007/s10311-011-0352-0

Ribeiro AR, Afonso CM, Castro PML et al (2013) Enantioselective HPLC analysis and biodegradation of atenolol, metoprolol and fluoxetine. Environ Chem Lett 11:83-90. https://doi.org/10.1007/ s10311-012-0383-1

Schaider LA, Rodgers KM, Rudel RA (2017) Review of organic wastewater compound concentrations and removal in onsite wastewater treatment systems. Environ Sci Technol 51(13):7304-7317. https ://doi.org/10.1021/acs.est.6b04778

Silva BFD, Jelic A, López-Serna R et al (2011) Occurrence and distribution of pharmaceuticals in surface water, suspended solids and sediments of the Ebro river basin. Spain Chemosphere 85(8):1331-1339. https://doi.org/10.1016/j.chemospher e.2011.07.051

Stanley JK, Ramirez AJ, Chambliss CK et al (2007) Enantiospecific sublethal effects of the antidepressant fluoxetine to a model aquatic vertebrate and invertebrate. Chemosphere 69(1):9-16. https://doi.org/10.1016/j.chemosphere.2007.04.080

Vazquez-Roig P, Segarra R, Blasco C et al (2010) Determination of pharmaceuticals in soils and sediments by pressurized liquid extraction and liquid chromatography tandem mass spectrometry. J Chromatogr A 1217(16):2471-2483. https://doi.org/10.1016/j. chroma.2009.11.033

Wilkinson J, Hooda PS, Barker J et al (2017) Occurrence, fate and transformation of emerging contaminants in water: An overarching review of the field. Environ Pollut 231:954-970. https://doi. org/10.1016/j.envpol.2017.08.032

Xue M, Qin Y, Gu X et al (2018) Determination of flumequine enantiomers and 7-hydroxyflumequine in water and sediment by chiral HPLC coupled with hybrid quadrupole-time-of-flight mass spectrometer. Sci Rep 8(1):7582. https://doi.org/10.1038/s4159 8-018-25889-5

Yuan X, Li X, Guo P et al (2018) Simultaneous enantiomeric analysis of chiral non-steroidal anti-inflammatory drugs in water, river sediment, and sludge using chiral liquid chromatography-tandem mass spectrometry. Anal Methods 10(36):4404-4413. https://doi. org/10.1039/c8ay01417e

Publisher's Note Springer Nature remains neutral with regard to jurisdictional claims in published maps and institutional affiliations. 